\title{
PROSES PRODUKSI, FUNGSI, PELUANG EKONOMI, DAN PENGEMBANGAN TENUN BUGIS PAGATAN KABUPATEN TANAH BUMBU KALIMANTAN SELATAN
}

\section{PRODUCTION PROCESS, FUNCTION, ECONOMIC OPPORTUNITY, AND BUGIS WEAVING DEVELOPMENT KABUPATEN TANAH BUMBU SOUTH KALIMANTAN}

\author{
Hendraswati \\ Balai Pelestarian Nilai Budaya Kalimantan Barat \\ Jln. Letjen Sutoyo Pontianak \\ tiwinabila383@gmail.com
}

\begin{abstract}
Pagatan's woven fabric is one of the important heritages in Indonesian culture because it reflects the knowledge of its high-value support community. Unfortunately, the social research on weaving Indonesia is still very limited. The purpose of this research is to see the production process, function, value, and economic opportunity, as well as the effort of developing Pagatan woven fabric in Tanah Bumbu Regency. This research is a qualitative research. Data were collected through observation techniques, in-depth interviews, and documentation. The results of this study indicate that weaving tradition is a skill belong to Bugis Pagatan migrant women in processing yarn into cloth. Fabrics are made traditionally using gedok. The function of the woven fabric can be seen from its daily use and during traditional ceremonies. This woven fabric has cultural symbols, social identity, and ethnicity. The beauty of the style, the quality of the material, and the peculiarity of the motive make this cloth has a selling point so that economic opportunities for the weavers. Efforts that can be done to preserve Pagatan weaving as one of the official clothing in government institutions, cultural events, build Pagatan weaving craft center, and used as a matter of local content at school.
\end{abstract}

Keywords: weaving, economy, and culture.

\begin{abstract}
ABSTRAK
Kain tenun Pagatan merupakan salah satu warisan penting dalam kebudayaan Indonesia karena mencerminkan pengetahuan masyarakat pendukungnya yang bernilai tinggi. Sayangnya, penelitian sosial yang membahas tentang tenun Indonesia masih sangat terbatas. Tujuan penelitian ini untuk melihat proses produksi, fungsi, nilai, dan peluang ekonomi,
\end{abstract}


serta upaya pengembangan kain tenun Pagatan di Kabupaten Tanah Bumbu. Penelitian ini merupakan penelitian kualitatif. Data dikumpulkan melalui teknik observasi, wawancara mendalam, dan dokumentasi. Hasil penelitian ini menunjukkan bahwa tradisi menenun merupakan keterampilan yang dimiliki wanita migran Bugis Pagatan dalam mengolah benang menjadi kain. Kain dibuat secara tradisional menggunakan gedok. Fungsi kain tenun tersebut dapat terlihat dari penggunaannya sehari-hari dan saat upacara adat. Kain tenun ini memiliki simbol budaya, identitas sosial, dan etnik. Keindahan corak, kualitas bahan, dan kekhasan motifnya membuat kain ini memiliki nilai jual sehingga peluang ekonomi bagi para penenunnya. Upaya yang dapat dilakukan untuk melestarikan tenun Pagatan sebagai salah satu pakaian resmi di lembaga pemerintahan, perhelatan budaya, membangun pusat kerajinan tenun Pagatan, dan dijadikan materi muatan lokal di sekolah.

Kata kunci: tenun, ekonomi, dan budaya.

\section{A. PENDAHULUAN}

Tenun merupakan seni dalam membuat motif desain berupa gambar yang dibuat dari benang yang panjang melintang untuk pakaian. Kerajinan tenun adalah salah satu kebudayaan materi yang merupakan budaya asli bangsa Indonesia. Tenun harus dilestarikan dan dikembangkan secara terus-menerus karena menyimpan sejumlah pengetahuan tradisional dan berbagai kearifan yang mengakar secara substansial, dilihat dari sisi ornamentasi keselarasan, proses pembuatannya, hingga cara mengapresiasinya.

Berkenaan dengan kain tenun ini, maka setiap daerah di Indonesia memiliki kekhasan dan tradisi dalam menenun. Itulah sebabnya, kain yang merupakan barang hasil tenunan memiliki beragam motif dan corak yang berbeda-beda. Keunikan motif dan corak tenun di berbagai daerah merupakan kekuatan yang sangat luar biasa, khususnya bagi kekayaan seni budaya Indonesia dan belum ada di negara manapun yang memiliki kekayaan rancangan motif yang unik pada tenun seperti yang dimiliki bangsa Indonesia.

Dalam perkembangannya sekarang ini, tidak hanya dikenal kain tenun batik Jawa dan atau kain songket Palembang, tetapi dikenal pula kain-kain dari daerah yang lain, baik kain tenun ikat, songket, maupun kain tenun yang dihasilkan dengan teknik yang lain. Semuanya merupakan kekayaan dan warisan tradisi leluhur bangsa Indonesia yang harus tetap dijaga dan dilestarikan.

Di Kalimantan Selatan telah pula berkembang dan dikenal secara luas kain tenun tradisional yang disebut sasirangan, yaitu kain khas masyarakat Banjar yang dibuat dengan dengan cara digambar atau dipola. Kain putih polos yang sudah dipola kemudian dijahit dan diikat, kemudian dicelup atau diberi warna untuk mendapatkan pola yang dikehendaki, hingga sampai proses berikutnya. 
Selain sasirangan, di Kalimantan Selatan juga dikenal jenis kain tradisional yang dinamakan kain tenun Pagatan. Dinamakan kain tenun Pagatan karena kain tenun ini hanya dibuat oleh para perajin di daerah Pagatan Kabupaten Tanah Bumbu Provinsi Kalimantan Selatan. Kain tenun Pagatan ini memang tidak sepopuler kain sasirangan, namun sebagai bagian potensi dan kekayaan tradisi yang dilakukan masyarakat pesisir bagian tenggara Kalimantan Selatan, eksotis tenun Pagatan penting untuk diungkap, sehingga pengetahuan tradisional proses pembuatan, fungsi, ataupun nilai dan peluang ekonomi dari tenun ini dapat diketahui dan terus dikembangkan.

Masyarakat setempat memahami bahwa keterampilan membuat kain tenun Pagatan dibawa dan dikembangkan seiring kedatangan orang-orang Bugis Wajo ke daerah Kalimantan Selatan, terutama Pagatan dan sekitarnya pada abad ke-18 M. Kedatangan mereka dimulai oleh rombongan pedagang yang dipimpin oleh bangsawan Bugis. Setelah mendapat izin tinggal dari Kesultanan Banjarmasin, mereka kemudian membuka daerah Pagatan di sepanjang Sungai Kusan serta mendirikan kerajaan yang dinamakan Kerajaan Pagatan. Daerah ini semakin berkembang dan menjadi kawasan tinggal serta persebaran dari diaspora Bugis yang datang kemudian. Kedatangan orang-orang Bugis dengan berbagai latar belakang ke Pagatan membawa serta tradisi dari tanah asal mereka, di antaranya adalah tradisi menenun, yakni mengolah benang menjadi kain dengan warna, motif, nilai-nilai dan makna-makna tertentu (Wawancara Andi Satria Jaya, Pagatan, 12 April 2016).

Secara umum, teknik pembuatan kain Pagatan berbeda dibandingkan dengan pembuatan kain sasirangan dan batik. Tenun Pagatan dihasilkan melalui proses penenunan dengan menggunakan alat tenun tradisional yang disebut gedok, sehingga pembuatan corak, gambar, motif, atau pola dilakukan secara langsung melalui proses tenun dengan memadukan berbagai benang warna. Sedangkan pada kain sasirangan dan batik, motif atau pola dibuat dengan cara digambar. Kain sasirangan misalnya, halang rintang warna dilakukan dengan menggunakan benang yang dijahitkan atau dijelujur mengikuti motif tertentu, kemudian ditarik dan diikat dengan kuat. Kerutan jelujur inilah nantinya yang akan menghalang warna celupan pada kain sehingga menyisakan motif sesuai dengan yang diinginkan. Pada teknik rintang warna pada batik, reka latarnya diperoleh dari halang rintang dengan bahan lilin (malam) yang dioles pada permukaan kain yang telah diberi atau digambari motif tertentu. Kain kemudian dicelup warna dan halang rintangnya dilarutkan pada air panas, sehingga tertinggal motif yang diinginkan (Sulaksono, 2015: 5).

Kain tenun Pagatan tidak hanya terlihat indah karena kelembutan 
warnanya, tetapi juga dari corak atau motif khas yang terpola pada kain. Dilihat dari segi warna misalnya, warna kain tenun Pagatan merupakan warna perpaduan dalam tradisi orang-orang Bugis dan orang-orang Banjar yang sifatnya bertolak belakang. Menurut tradisi orang-orang Bugis, warna kain atau pakaian yang mereka buat biasanya didominasi oleh warna tua, sementara warna tradisional orang Banjar didominasi oleh warna cerah dan muda. Sekarang, sebagai hasil perpaduan warna, banyak kain Pagatan yang dibuat dengan warna yang lebih cerah. Sebaliknya, banyak pula kain sasirangan yang dibuat dengan warna yang lebih tua.

Begitu pula dengan motif, ada beberapa nama motif khas tenun Pagatan, seperti motif pakajucilla, capu paranga, capu kaluku, bintang betaburan, dan rentete mannanrang. Dalam perkembangannya, telah terjadi pembauran antara motif kain tenun Pagatan yang khas etnik Bugis dengan motif kain sasirangan yangkhas etnik Banjar. Motif kain sasirangan seperti gigi haruan, gagatas, dan halilipan dapat dipadukan dengan motif gelombang yang menjadi motif khas pada kain orang Bugis.

Terjadinya perpaduan warna, pola atau motif antara kain sasirangan (Banjar) dan kain tenun Pagatan (Bugis) inisecara jelas menunjukkan terjalinnya dua hubungan budaya secara harmoni (Hidayah, 2014: 17). Hal ini sekaligus pula menunjukkan adanya saling tukar budaya, saling memengaruhi, daya kreativitas, inovasi, dan imajinasi dari masing-masing penenun untuk memadukan dua pola dari tradisi yang berbeda dan kemudian menghasilkan pola baru. Namun pola baru itu tetap mencirikan atau menunjukkan masingmasing pola dasar yang bersifat khas dari tradisi kedua etnik.

Dewasa ini pemerintah tengah berupaya untuk melestarikan dan mengembangkan berbagai potensi serta tradisi tenun dari berbagai daerah di Indonesia. Seiring dengan upaya tersebut, tenun Pagatan pun perlu untuk terus dibina dan dikembangkan. Terlebih pada masa sekarang, kain tenun Pagatan perlu mendapat perhatian yang serius dari berbagai pihak karena menghadapi berbagai kendala dan tantangan. Apabila tidak diupayakan pelestariannya, maka tidak mustahil suatu saat nanti tenun Pagatan sebagai hasil dari suatu tradisi akan hilang dan tercerabut dari masyarakatnya. Gejala tersebut setidaknya sudah terlihat dari semakin sedikitnya kaum wanita Bugis Pagatan yang mau menggeluti usaha ini dan kurangnya minat remaja putri Bugis Pagatan untuk mempelajari dan meneruskan tradisi tenun Pagatan. Upaya pembinaan terhadap kain tenun Pagatan sebagai aset kebudayaan dan potensi kekayaan lokal perlu dilakukan secara terus menerus, supaya tenun ini dapat terus bertahan dan berkembang di tengah masyarakat luas.

Berdasarkan uraian di atas, permasalahan utama yang menjadi fokus dalam penelitian adalah kain tenun Pagatan, menyangkut tentang 
proses pembuatan, fungsi, nilai ekonomi, dan upaya pengembangan kain tenun Pagatan dalam kehidupan masyarakat Bugis Pagatan. Sedangkan tujuan penelitian adalah untuk mengeksplorasi pengetahuan dan tradisi masyarakat Bugis Pagatan dalam membuat kain tenun, terutama menyangkut keempat permasalahan utama yang menjadi fokus penelitian.

Tenun adalah hasil karya berupa kain yang dibuat dari benang (kapas atau sutra) dengan cara memasukan pakan secara melintang pada lungsin, yakni benang tenun yang disusun sejajar dan biasanya memanjang (vertikal). Menenun berarti membuat barangbarang tenunan dari benang kapas, sutra, dan lain-lain, misalnya kain (Kamus Bahasa Indonesia, 2008:1683). Barang yang dihasilkan dari kegiatan menenun adalah kain, yang bermakna barang tenunan pada umumnya; barang tenunan yang dikenakan untuk sarung, pakaian, atau pun untuk maksud yang lain (Kamus Bahasa Indonesia, 2008: 658).

Berdasarkan pengertian di atas, maka tenun merupakan teknik dalam pembuatan kain yang dibuat dengan prinsip yang sederhana namun detail, yaitu dengan menggabungkan benang secara memanjang dan melintang. Dengan kata lain, teknik utama dalam membuat kain tenun adalah melakukan persilangan antara benang lungsin dan pakan secara bergantian.

Setidaknya ada dua jenis utama dari kain tenun, yakni jenis tenun songket dan tenun ikat. Tenun songket merupakan tenun yang dibuat dengan benang emas atau perak, sedangkan tenun ikat dibuat dengan teknik ikat, baik ikat pada benang pakan ataupun pada benang lungsin. Ada ikat ganda, ada pula ikat pakan.

Tradisi tenun ikat adalah tradisi menenun yang tersebar luas di berbagai pelosok wilayah di Indonesia, misalnya pada masyarakat Batak (Sumatera Utara), masyarakat daerah Kepulauan Flores, Sumba, Rote, Sabu, Ndao, dan Timor (Nusa Tenggara Timur). Begitu juga pada masyarakat Dayak di Kalimantan, daerah Rongkong dan Galumpang di Sulawesi, serta di Kepulauan Maluku. Kain Tanimbar dan Kisar juga merupakan tenun ikat. Kemudian, daerah Palembang dan Pasemah di Sumatera Selatan, di Kepulauan Bangka, Belitung, dan daerah pesisir Timur Sumatera, di Donggala dan Bugis (Sulawesi Selatan), di daerah Gresik dan Lamongan (Jawa Timur), serta di Bali yang terkenal dengan tenun ikat geringsing yang ditenun oleh penenun di Desa Tenganan (Sulaksono, 2015: 14).

Secara umum, tenun ikat dilakukan dengan teknik mengikat benang. Bagian kain yang berupa benang lungsin dibiarkan tidak diwarnai, kemudian diberi lapisan pelindung benang dengan cara mengikatnya kuat-kuat menggunakan bahan serat tanaman. Fungsinya adalah untuk menghindari tekanan resapan dari zat warna pada waktu pewarnaan benang. Ikatan ini dilepaskan setelah kain diberi warna, 
sehingga akan memunculkan motif tertentu pada warna kain. Teknik ikat seperti ini bisa pula diterapkan pada dua sisi benang, yakni pada benang yang dipasang pada posisi vertikal (lungsin) dan benang yang dipasang pada posisi horizontal (pakan). Teknik ikat benang lungsin maupun teknik ikat benang pakan dapat diterapkan sekaligus pada saat pembuatan tenun. Penerapan kedua teknik ikat seperti ini disebut sebagai teknik ikat ganda, yang dilakukan dengan cara benang lungsin dan benang pakan diikat secara terpisah dan diwarnai masing-masing dengan motif tertentu, misalnya dalam bentuk garis, bangun geometris, segitiga, tumpal, tanaman (flora), dan lain-lain (Sulaksono, 2015: 7).

Kain tradisional menjadi bagian dari kekayaan bangsa Indonesia karena merupakan hasil dari kegiatan atau tradisi menenun yang didasari pengetahuan tradisional dan keterampilan yang sudah dimiliki sejak dahulu serta diwariskan oleh bangsa Indonesia dari satu generasi ke generasi berikutnya. Keberadaan kain tenun juga mengiringi perjalanan sejarah berbagai etnik di Indonesia. Setiap daerah di Indonesia memiliki kain tradisional yang bersifat khas dan menyiratkan keluhuran tradisi dengan keragaman motif, fungsi, dan makna simbolisnya masing-masing (http://informationofworld.blogspot.co.id/2014/10/macammacam-kain-makna-simbolik.html). Kain batik bagi orang Jawa, misalnya, memiliki kegunaan yang sangat banyak. Tidak hanya sebagai bahan untuk membuat pakaian yang dikenakan dalam kegiatan sehari-hari, melainkan dikenakan pula dalam kegiatan atau upacara adat, serta diterapkan sebagai penutup pada sejumlah peralatan rumah tangga, seperti taplak meja, tirai, sarung kasur, selimut, dan lain-lain.

Pada orang Batak, kain ulos dipergunakan secara meluas di berbagai tempat dan kesempatan sesuai dengan fungsinya. Dari dulu hingga sekarang ulos dijadikan sebagai medium pemberian doa restu atau pemberkatan dari orangtua kepada anak menantunya (perempuan), kakek-nenek kepada cucunya, paman (tulang) kepada keponakan (bere), raja kepada rakyat, dan lain-lain. Sambil menyampaikan ulos, pihak yang dihormati (pemberi) menyampaikan doa restu atau pemberkatan (umpasa) dan pesan (tona) untuk menggembirakan dan merestui si penerima ulos. Selain itu, ulos juga mengiringi perjalanan hidup seseorang di setiap langkah yang dilaluinya. Dengan kata lain, orang Batak akan selalu mengenakan ulos ketika dia melaksanakan upacara atau tradisi adat saat berada di satu fase dalam lingkaran daur hidupnya. Ulos memiliki beragam jenis dan fungsi, misalnya, ulos jenis antakantak yang dipakai sebagai selendang orangtua untuk melayat orang yang meninggal; ulos yang dipakai sutra sebagai kain yang dililit pada waktu acara manortor (menari tari Tortor); ulos jenis bintang maratur yang biasanya dipakai atau diberikan kepada anak yang memiliki rumah baru, anak yang selamatan hamil 
7 bulan, pahompu (cucu) yang baru lahir sebagai parompa (alat untuk menggendong); ulos jenis bolean yang biasanya dipakai sebagai selendang pada acara-acara kedukaan; serta ulos jenis mangiring yang dipakai sebagai selendang.

Kain tenun songket Palembang memiliki berbagai makna sesuai dengan motifnya. Beberapa contoh di antaranya adalah motif bunga mawar yang dipercaya sebagai penawar malapetaka. Biasanya songket dengan motif ini dipakai pada upacara cukur rambut bayi, khususnya dipakai selimut dan kain gendongan. Motif bunga tanjung melambangkan sikap keramahtamahan dari tuan rumah dan sebagai lambang ucapan selamat datang kepada siapa saja yang bertamu. Motif bunga melati melambangkan sopan santun, keanggungan, dan kesucian. Motif ini biasanya digunakan oleh gadis-gadis dalam lingkup kerajaan yang belum menikah karena motif bunga melati menggambarkan kesucian. Motif pucuk rebung melambangkan harapan yang baik sebab bambu merupakan pohon yang tidak mudah rebah oleh tiupan angin kencang sekalipun.

Selain batik, ulos, dan songket Palembang masih banyak lagi jenis kain khas yang berasal dari berbagai daerah di Indonesia. Misalnya, kain tapis dari Lampung; kain cepuk, poleng, prada, dan gringsing dari Bali; kain tenun bentenan dari Minahasa; serta kain sasirangan dari Banjarmasin. Kain-kain tersebut memiliki fungsi dan makna simbolis masing-masing yang memiliki keterkaitan dengan kebudayaan yang mereka miliki, karena kain tersebut hampir selalu digunakan saat upacara atau tradisi adat yang dilaksanakan di sepanjang siklus kehidupan mereka. Hal lain yang juga penting dari kain tradisional ini adalah bahwa semua jenis kain tersebut dibuat melalui proses penenunan yang teliti dan memerlukan keahlian tersendiri, sehingga sarat dengan makna, seni, dan kearifan lokal yang terkandung di dalamnya.

Penelitian ini merupakan penelitian lapangan yang bersifat deskriptif kualitatif untuk mengkaji permasalahan utama tentang seluk beluk atau proses pembuatan kain tenun Pagatan. Permasalahan ini penting untuk dikaji, karena kain tradisional adalah produk kebudayaan dari suatu masyarakat yang bernilai seni tinggi, dihasilkan melalui proses yang panjang, dan sarat dengan fungsi serta makna-makna penting ataupun kearifan lokal di dalamnya. Selain itu, kain tenun Pagatan adalah bagian dari warisan dan kekayaan bangsa Indonesia yang harus dilestarikan dan dikembangkan. Oleh sebab itu, penelitian ini menjadi penting untuk dilakukan.

Penelitian ini dirancang sesuai dengan prinsip-prinsip dalam penelitian kualitatif. Menurut Basrowi dan Suwandi (2008:20), penelitian kualitatif merupakan penelitian yang dilakukan berdasarkan paradigma, strategi, dan implementasi model secara kualitatif.

Berkenaan dengan pendekatan yang digunakan, maka penelitian ini dirancang dengan menggunakan 
pendekatan atau model penelitian studi kasus. Penelitian studi kasus sebagaimana dijelaskan oleh Surachmad (1982) dilakukan dengan memusatkan perhatian pada suatu kasus secara intensif dan rinci, yang dalam hal ini adalah kain tenun Pagatan. Lokasi penelitian adalah Pagatan yang merupakan ibu kota dari Kecamatan Kusan Hilir dan menjadi kawasan sentral perajin kain tenun Pagatan. Secara geografis Kecamatan Kusan Hilir terletak pada 03034' 11''03038'14'' Lintang Selatan dan 115 ${ }^{\circ} 7^{\prime}$ 4'-115059'43' Bujur Timur dengan luas wilayah 401,54 km². Kecamatan yang terletak di Kabupaten Tanah Bumbu (Kalimantan Selatan) ini terbagi menjadi 34 desa dan 1 kelurahan. Sebagian besar penduduknya bermata pencaharian utama sebagai nelayan dan bertani. Mereka berdiam pada wilayahwilayah permukiman yang terdiri atas wilayah pesisir pantai, wilayah rancah atau rawa, wilayah daratan, wilayah pemerintahan dan nelayan.

Pagatan dipilih sebagai lokasi penelitian dengan beberapa pertimbangan, yakni wilayah ini merupakan permukiman awal orang Bugis, bekas pusat kota Kerajaan Bugis Pagatan, daerah sentral yang menjadi tujuan utama diaspora Bugis di bagian tenggara Kalimantan Selatan, serta satusatunya kawasan yang menjadi tempat tinggal para perajin kain tenun Bugis Pagatan.

Objek penelitian adalah kain tenun. Tujuannya adalah untuk melihat proses produksi, fungsi, nilai, peluang ekonomi, serta upaya pengembangannya. Data utama dikumpulkan secara langsung di lapangan dengan menggunakan teknik observasi di sentra-sentra pembuatan tenun Pagatan, wawancara secara mendalam dengan para perajin, pemilik sentra tenun Pagatan, budayawan, maupun pemerintah daerah dan pihak terkait, serta studi dokumentasi terhadap sejarah keberadaan dan perkembangan tradisi kain tenun Pagatan.

\section{B. HASIL DAN BAHASAN}

\section{Proses Pembuatan}

Tenun Pagatan dihasilkan oleh tangan-tangan terampil melalui proses matenung atau itenung (menenun) yang cukup panjang. Proses penyelesaian selembar kain tenun memerlukan waktu antara 2 minggu hingga 3 bulan, tergantung dari motif yang akan dibuat. Penenunan dimulai dari proses pemintalan benang, pemberian warna pada benang, hingga penyusunan dan pembentukan benang menjadi motif dan ragam hias. Rangkaian dari proses yang panjang ini memunculkan pola dan corak yang beragam, menawan, serta mengesankan keindahan. Tenun yang berkualitas dihasilkan dari proses yang tidak mudah karena memerlukan ketelitian, keahlian, dan kesabaran. Selain itu dibutuhkan pula berbagai bahan yang berkualitas terutama benang, peralatan tenun yang memadai, serta kecerdasan teknik menenun yang telah diwarisi sekian lama. Semua faktor pendukung tersebut berpadu 
menjadi satu, guna menghasilkan kain tenun khas Pagatan.

Pada masa lalu, sebagaimana umumnya yang berlaku pada berbagai kelompok masyarakat adat di Indonesia, masyarakat Bugis juga mempunyai pandangan bahwa aktivitas menenun merupakan kebanggaan kaum wanita. Pada 1900-an, sebagian besar kaum wanita Bugis Pagatan pandai menenun, sehingga apabila ada kerabat Kerajaan Pagatan ingin membuat sarung tenun, maka para perajin diundang ke Seroja (istana Kerajaan Pagatan). Tradisi di Kerajaan Pagatan ini menjadi kebanggaan dan bisa mengangkat kehidupan para perajin menjadi lebih baik dan bergengsi. Keterampilan menenun dianggap sangat penting dan harus dikuasai oleh kaum wanita Bugis Pagatan, selain kepandaian memasak dan pekerjaan rumah tangga yang lainnya. Begitu penting dan membanggakannya keterampilan menenun ini hingga membuatnya disejajarkan dengan keterampilan atau kemampuan laki-laki dalam hal berdagang dan berlayar, melaut, atau membuat kapal.

Dahulu seluruh proses pembuatan kain tenun Pagatan hanya dilakukan oleh kaum wanita. Namun sekarang terkadang kaum laki-laki juga turut terlibat di dalam proses produksi. Kaum laki-laki yang istrinya memiliki usaha membuat tenun Pagatan ada yang turut membantu pekerjaan istrinya, terutama di saat waktunya kosong, atau tidak melaut. Keterlibatan kaum lakilaki seperti ini jarang sekali ditemukan.
Keterlibatan kaum laki-laki dalam proses produksi diakui oleh seorang informan disebabkan oleh alasan psikologis. Para pria yang sedang tidak bekerja (misal, tidak melaut) dan berarti tidak menghasilkan pendapatan finansial akan mempersepsikan dirinya sebagai sosok pria yang tidak berguna. Untuk menghapus persepsi tersebut, para pria bekerja sama dengan istrinya meski terbatas pada proses pemintalan atau pewarnaan benang, penjemuran benang, hingga benang siap untuk ditenun menjadi kain (Wawancara Ishak, Pagatan, 14 April 2016).

Secara umum, kain tenun Pagatan dibuat melalui beberapa proses atau tahapan, dimulai dari penyiapan bahan dan peralatan, hingga proses penenunan. Di setiap tahapan dalam proses penenunan ini dominan dilakukan oleh kaum wanita Bugis Pagatan.

\section{a. Bahan: Benang Tenun, Pewarna Benang dan Pengawet Benang}

Bahan utama yang diperlukan untuk menenun kain Pagatan adalah benang tenun, bahan pewarna, dan bahan pengawet.

Benang tenun yang dipakai oleh perajin tenun Pagatan biasanya terdiri dari empat jenis, yang dibagi berdasarkan tingkat kualitasnya, yakni benang sutra, benang Singapura,benang Samarinda, dan benang biasa. Pada zaman dahulu benang sutra yang digunakan untuk membuat tenun Pagatan didatangkan dari Sulawesi Selatan secara langsung, karena pada 
saat itu benang sutra tidak tersedia di Kalimantan Selatan. Di masa itu hubungan antara Kalimantan Selatan dengan Sulawesi Selatan lebih mudah jika dibandingkan dengan Pulau Jawa. Bahan yang didatangkan dari Sulawesi tersebut kemudian diolah oleh para perajin di Pagatan. Benang sutra yang digunakan itu dipilih dan berasal dari sutra alam yang dihasilkan oleh ulat sutra. Para penenun tahu bahwa sutra alam merupakan bahan yang kualitasnya paling baik. Namun saat ini, para penenun kain Pagatan sudah jarang menggunakan bahan sutra alam, kecuali jika ada yang memesan. Bahan sutra alam ini tidak lagi harus didatangkan dari Sulawesi Selatan. Kini para penenun lebih sering membelinya dari Pulau Jawa. Biasanya dari satu bal benang sutra seberat $5 \mathrm{~kg}$ yang dibeli dengan harga $\mathrm{Rp}$ 1,6 juta, dapat dihasilkan 15 lembar kain atau sarung. Atau, dari tiap $1 \mathrm{~kg}$ benang sutra dapat dihasilkan sekitar 3 lembar kain.

Apabila penenun kain Pagatan tidak menggunakan benang sutra, maka mereka menggunakan benang Samarinda dan benang Singapura sebagai gantinya. Benang Samarinda adalah benang yang digunakan untuk membuat sarung Samarinda. Benang ini tidak diolah secara tradisional, namun dibuat oleh pabrik benang. Para penenun memesan dan membeli benang Samarinda dari Pulau Jawa. Sama seperti benang Samarinda, benang Singapura pun merupakan benang buatan pabrik. Meskipun kualitas benang Singapura lebih baik daripada benang Samarinda, namun kualitasnya masih lebih rendah dibandingkan dengan benang sutra alam.

Selain benang Samarinda dan benang Singapura, terdapat satu jenis benang lagi yang bisa dipakai untuk membuat tenun Pagatan, yakni benang biasa. Benang ini bisa diperoleh dengan memintal sendiri, tetapi bisa juga dengan membeli benang biasa yang merupakan buatan atau produksi pabrik. Benang-benang seperti ini sudah banyak tersedia dan dijual di toko-toko di Pagatan, bisa juga dibeli di Banjarmasin, bahkan untuk keperluan yang lebih besar biasanya didatangkan secara langsung dari Pulau Jawa.

Pada umumnya para penenun menggunakan benang buatan pabrik yang bewarna putih polos. Tetapi benang yang bewarna lain bisa digunakan jika warna benang tersebut sesuai dengan motif atau ragam hias yang diinginkan. Proses pewarnaan benang biasa yang bewarna putih polos dapat dilakukan dengan memberi warna pada benang itu sesuai dengan warna yang dikehendaki.

Bahan pewarna bersumber dari alam. Proses penciptaan warna tersebut merupakan pengetahuan tradisional yang bernilai tinggi sebagai hasil dari uji coba yang dilakukan dalam jangka waktu yang begitu lama. Bahan pewarna yang biasanya digunakan ialah kesumba dan daun kabuau untuk warna hitam. Kabuau adalah sejenis tumbuhan yang buahnya digunakan sebagai kelereng dalam permainan anak-anak di wilayah pedesaan di Kalimantan 
Selatan. Sebelum digunakan untuk mewarnai, daun kabuau direbus hingga air rebusannya bewarna hitam. Air rebusan daun kabuau yang berwarna hitam inilah yang dijadikan sebagai pewarna benang. Benang yang akan diwarnai cukup dicelupkan atau direndam di dalam air pewarna ini. Setelah proses pencelupan atau perendaman ke dalam air rebusan daun kabuau selesai dilakukan, proses pewarnaan dilanjutkan lagi dengan merendam benang ke dalam tanah lumpur selama satu malam untuk menguatkan warna hitamnya. Pada tahap akhir dilakukan proses pencucian dan pengeringan dengan cara menjemur benang yang telah diwarnai tersebut.

Bahan pewarna non-alami yang bisa juga digunakan untuk mewarnai benang tenunan adalah pewarna buatan pabrik, yakni wantek. Warna wantek yang beraneka ragam memudahkan penenun untuk berkreasi dan memadukan berbagai warna untuk menghasilkan corak tenun yang sesuai dengan keinginan mereka. Cara menggunakannya adalah dengan mencelupkan benang putih polos ke dalam air yang sudah dicampur dengan wantek, kemudian mendiamkannya selama beberapa waktu, hingga warna benar-benar telah meresap atau menjadi satu dengan benang. Terkadang proses ini dilakukan secara berulang-ulang. Pewarna buatan atau wantek biasanya dibeli di toko kain, baik secara grosiran ataupun eceran. Pada dasarnya para perajin tenun Pagatan lebih suka menggunakan pewarna alami, karena pewarna alami tidak mudah luntur.

Teknik pewarnaan benang untuk tenun Pagatan berbeda dengan teknik pewarnaan benang untuk kain sasirangan. Dahulu perajin kain sasirangan memakai benang dari serat tanaman dan katun dengan dominasi warna merah, biru, kuning, hijau, dan putih. Bahan pewarna benang menggunakan pewarna alami yang berasal dari bagian tanaman tertentu dan uwar (kulit kayu) yang direndam ke dalam air sungai guna menyimpan larutan getah resin di dalamnya. Kekuatan warna dan struktur serat dari benang yang dilarutkan dengan cara seperti ini dianggap dapat bertambah tinggi, sehingga kain yang ditenun dari benang ini nantinya akan lebih tahan lama. Saat ini pewarnaan dilakukan secara langsung dengan teknik jelujur pada kain putih polos mengikuti polapola yang telah dibuat atau dijahit sebelumnya.

Pada tenun Pagatan proses pewarnaannya sudah mulai dilakukan sejak pembuatan atau pemintalan benang. Proses tersebut dilanjutkan dengan pemilihan warna benang yang sudah jadi, sesuai dengan corak atau pola yang diinginkan, yang dilanjutkan dengan proses penenunan atau penyilangan antarbenang yang berbeda warna.

Agar warna benang tidak cepat luntur (lebih tahan lama), maka digunakan bahan pengawet alami. Bahan pengawet yang biasa digunakan adalah bahan pengawet tradisional, 
Handep, Vol. 1, No. 2, Juni 2018 : 35-58

yakni buah kelapa yang masih sangat muda dan kulit jambu mente. Proses pengawetannya dilakukan dengan cara sebagai berikut: 1) semua bahan ditumbuk, kemudian dicampur dengan air; 2) campuran tersebut disaring untuk memisahkan air dari ampasnya; 3) benang yang sebelumnya sudah diwarnai dicelupkan ke dalam larutan air tersebut.

Proses pengawetan benang ini umumnya dilakukan bersamaan dengan proses pewarnaan benang. Oleh karena itu, pada benang bewarna buatan pabrik biasanya tidak dilakukan proses pengawetan seperti yang dilakukan pada benang yang dihasilkan dari proses pemintalan sendiri. Selain sulit untuk dilakukan, proses pengawetan pada benang bewarna buatan pabrik justru bisa mengubah warna benang.

\section{b. Peralatan Tenun}

Peralatan tenun yang digunakan untuk membuat tenun Pagatan kurang lebih sama dengan yang peralatan tenun tradisional yang dipakai oleh para penenun dari Sulawesi Selatan. Namun, peralatan tenun yang digunakan di daerah Pagatan dan sekitarnya dibuat dari kayu yang banyak terdapat di daerah itu.

Beberapa peralatan yang digunakan untuk membuat kain tenun Pagatan antara lain adalah gedok atau alat tenun yang terbuat dari kayu, roweng, ola, unuseng, pamedangan, saureng, patekko, palapa atau belebas, pacucukkare, awereng, are, jakka, pamalu, pessa, simong, tamrajeng, boko-boko, bulang, papanenre, walida, sakka, pa'jeloreng, sumpung, dan pabican.

Roweng atau mesin uluran adalah alat yang digunakan untuk mengulur atau membuka benang dari gulungannya. Ola digunakan untuk menggulung benang tenun. Unuseng atau papali adalah mesin pemutar yang dipergunakan untuk memutar benang pasulu (benang pakan). Pamedangan adalah alat yang digunakan untuk mengikat benang pada tenun ikat sebelum dicelupkan ke dalam bahan pewarna. Saureng, yaitu alat yang dipakai untuk menyusun benang sau atau benang dirian. Patekko adalah alat untuk menahan benang pakan dan benang lungsin. Belebas, yaitu alat yang dipakai untuk memisahkan benang dirian. Awereng atau penggulung adalah alat yang digunakan untuk membuat sela/jarak pemisah di antara benang sau. Pacucukkare juga digunakan sebagai alat pemisah benang sau. Are, yaitu alat untuk mengatur dan menyelipkan benang tenun pada waktu proses pembuatan ornamen pada kain tenun Pagatan yang berupa songket so'bbe are. Jakka [bahasa Banjar: sumbi] atau sisir yang berfungsi untuk merapikan benang dan untuk menjaga tepi kain agar tetap lebar.

Peralatan lain yang juga digunakan dalam menenun adalah pamalu, yaitu alat untuk menggulung benang sau yang belum ditenun. Pessa atau hapit adalah alat untuk menggulung kain yang sudah ditenun, atau alat untuk menggulung benang sau yang sudah 
ditenun dengan benang pasulunya. Simong adalah alat untuk menempatkan pamalu. Tamrajeng adalah alat yang dipergunakan untuk merapatkan benang pasulu. Boko-boko [bahasa Banjar: pampaut] adalah alat untuk merentangkan benang sau. Bulang [bahasa Banjar: tali tampar] adalah alat yang berfungsi untuk menghubungkan boko-boko, sehingga membuat benang dirian menjadi kencang. Papanenre [bahasa Banjar: papan katinjakan] merupakan alat yang berfungsi sebagai tempat kaki berpijak. Walida [bahasa Banjar: walira] berfungsi untuk membuat ruang pemisah di antara benang sau, sehingga akan memudahkan dalam memasukkan turak atau teropong yang berisi anagaliri atau lerengan yang berisi benang pasulu yang sudah digulung. Pa'jeloreng adalah alat yang digunakan untuk menyandarkan walida pada waktu menenun kain, sambil melemparkan atau memasukan turak atau teropong yang berisi anagaliri atau lerengan benang pasulu. Sumpung, yaitu alat yang digunakan untuk menyambung benang yang putus pada waktu proses menenun dilakukan. Pekerjaan orang yang menyambung benang ini disebut manyumpung. Pabican adalah alat yang terbuat dari bambu yang diikatkan ke bahu (punggung) walida untuk memudahkan dalam mengangkat susunan benang pasulu di saat membuat ruang pemisah di antara benang sau.

\section{c. Proses Penenunan}

Matenung atau itenung, yang dalam bahasa Bugis Pagatan berarti menenun, mengenal adanya beberapa teknik. Teknik tersebut bisa dikelompokkan berdasarkan cara menenun, cara membuat hiasan pada kain tenun, serta jenis kain tenun yang dihasilkan. Beberapa jenis kain yang dihasilkan dari aktivitas menenun ini adalah tenun ikat (bebbe); songket (so'bbe), baik sarung songket so'bbe are maupun sarung songket so'bbe sumelang; sarung jenis panji; dan sarung kotakkotak biasa (Sjarifuddin, et al., 1991: 26-30).

Proses pembuatan kain tenun ikat (bebbe) berbeda dengan kain tenun songket (so'bbe), baik dilihat dari proses awal pembuatannya, teknik pembuatan ornamen hias maupun motif pada kain. Pada kain tenun bebbe dikenal adanya teknik mengikat benang pada kulit batang pisang, yang dalam bahasa Bugis Pagatan disebut dengan membebbe. Itulah sebabnya tenun ini dinamakan tenun bebbe. Berikut ini adalah gambaran mengenai langkahlangkah dalam membuat tenun bebbe. Langkah pertama disebut dengan mangola, yaitu memasukkan seikat benang tenun ke dalam ruweng, yang kemudian digulung dengan gulungan benang (ola) yang dibuat khusus untuk membuka benang dari gulungan aslinya (gincilan). Langkah berikutnya adalah makajuneng, yaitu memindahkan benang dari ola ke ajuneng. Di tahap ini dilakukan penghitungan berapa banyak benang yang akan diikat dengan 
kulit batang pisang, sebelum dicelupkan ke dalam zat pewarna. Langkah ketiga adalah membebbe, yakni mengikat benang yang telah berada di ajuneng sesuai dengan pola yang diinginkan. Langkah keempat disebut ikasumba, yakni proses pemberian warna pada benang dengan cara mencelup benangbenang yang telah diikat ke dalam zat pewarna. Langkah kelima adalah irakui atau menjemur benang sampai kering, setelah benang-benang tersebut melewati tahap pewarnaan dan pembersihan. Langkah keenam adalah mabuka bebbe atau tahap membuka ikatan benang yang telah kering setelah dijemur. Langkah ketujuh disebut dengan dipali, yaitu proses yang dilakukan untuk menggulung benang. Alat yang dipakai adalah onoseng atau lerengan untuk melereng benang pasulu. Pasulu adalah benang pakan yang dianyamkan ke dalam benang dirian pada waktu menenun. Setelah semua tahapan ini selesai dan semua peralatan sudah disiapkan barulah proses menenun dilakukan dengan menggunakan gedok yang tergolong ke dalam Alat Tenun Bukan Mesin.

Proses atau tahapan awal dalam pembuatan kain tenun Pagatan jenis songket adalah ikasumba, yakni memberi warna pada benang tenun yang akan dijadikan bahan tenun tanpa diikat. Kedua, ipandre atau menganji, yakni mencelupkan benang yang akan digunakan untuk bahan tenun ke dalam tepung kanji yang telah dimasak terlebih dahulu. Fungsi dari tepung kanji ini adalah untuk mengeraskan benang. Ketiga adalah mangola, yaitu menganyam benang tenun sesuai dengan pola yang telah dibuat.

Berkenaan dengan motif atau pola kain, pada umumnya kain tenun Pagatan mempunyai motif atau pola dasar, yang kemudian dijadikan sebagai pedoman dalam mengembangkan beragam motif lainnya. Ada beberapa pola dasar dari ragam hias tenun Pagatan. Namun pola yang terpenting dan biasanya selalu ada sebagai ciri khas pada tenun Pagatan adalah adalah motif pagar sasirangan, segitiga maupun kotak. Selain ketiga motif dasar tadi, dikenal pula motif-motif lain, seperti: burung, kuda, keris, pohon kayu, anak panah, angsa, rantai, singa, naga, kelinci, jambangan bunga, kembang bakung, kaligrafi, dan sebagainya. Orientasi motif khas tenun Pagatan lebih mengarah kepada lingkungan alam dan pantai, sesuai dengan kondisi daerah yang mengitari Pagatan, di mana penduduknya kebanyakan bekerja sebagai nelayan.

Terdapat perbedaan motif pada kain tenun Pagatan yang berjenis tenun songket dengan yang berjenis tenun ikat. Menurut Salmah, terdapat 5 jenis motif yang dikenal pada tenun Pagatan, yakni motif ikat pakan, ikat lusi, salur, songket asli, dan songket biasa. Motif yang paling sulit dibuat namun memiliki nilai jual yang cukup mahal adalah motif songket asli. Hal ini disebabkan kain songket dengan motif songket asli membutuhkan waktu pengerjaan yang relatif lama, sekitar 3 bulan. Sedangkan kain tenun dengan 
motif ikat pakan dan lusi lebih singkat pengerjaannya, hanya memerlukan waktu kurang lebih setengah bulan. Apalagi sekarang sudah ada Alat Tenun Mesin (ATM), sehingga penenun dapat membuat motif ikat pakan dan ikat lusi dalam waktu yang pendek (Wawancara Salmah, Pagatan, 15 April 2016).

Jenis motif yang diterapkan pada kain songket dan sarung songket umumnya bermotif kotak-kotak segi empat, garis, dan garis-garis melintang. Motif-motif seperti ini memperlihatkan perbedaan warna yang mencolok. Motif yang terdapat pada jenis kain tenun yang dibuat dengan teknik ikat, atau yang disebut tenun ikat dan ikat ganda, lebih beragam. Kain-kain tenun ikat dapat dipenuhi oleh corak ragam hias geometris, tanaman, tumpal, dan segi tumpal, kapal layar, binatang, dan beberapa motif manusia. Pada umumnya corak ragam hias tersebut diperoleh melalui proses dan teknik pewarnaan benang.

Terdapat perbedaan pula dalam teknik pembuatan hiasan atau motif, antara tenun Pagatan yang berjenis bebbe (tenun ikat) dengan yang berjenis so'bbe (songket). Pada tenun jenis bebbe, penentuan corak dan ragam ornamen hias atau motifnya telah diatur sebelum benang dicelup, diberi warna, dan diikat sesuai dengan motif yang dikehendaki. Dengan kata lain, pada tenun ikat jenis bebbe, proses menenun benangnya dilakukan setelah benang tersebut dicelupkan ke dalam zat pewarna. Setelah itu dilakukan pengaturan benang tenun sesuai dengan ikatan pada waktu benang dicelupkan ke dalam pewarna, sehingga pada akhirnya terciptalah sebuah ornamen sesuai dengan corak yang diinginkan oleh penenun.

Kain tenun so'bbe terbagi menjadi dua, yakni so'bbe are dan so'bbe sumelang. Ragam hias dan motif dari tenun so'bbe are biasanya terdiri atas motif-motif kuno yang hanya boleh dikerjakan oleh seorang penenun yang memiliki keahlian tinggi. Pada tenun so'bbe are, ornamennya dibuat hinggamenembus ke sebelah dalam (balik kain sisi bagian depan). Caranya adalah dengan menyisipkan benang tenun di kedua sisi kain untuk membuat dan memunculkan ornamen tersebut, Meskipun ornamen yang diterapkan pada tenun so'bbe are terdapat di kedua sisi kain, tetapi yang terlihat lebih indah dan jelas hanya di satu sisi saja. Pada mulanya kain tenun so'bbe are dipergunakan di kalangan terbatas, misalnya golongan raja dan bangsawan. Fungsinya adalah sebagai bahan yang disertakan dalam acara pinangan, serta pelengkap busana yang dikenakan pada acara-acara yang bersifat khusus. Sedangkan pada kain tenun so'bbe sumelang, ornamen atau motifnya dibuat dengan cara menyisipkan benang songket atau pitte sumelang hanya pada bagian muka saja (satu sisi kain). Karena ornamen tidak dibuat hingga tembus ke dalam, maka ornamen tersebut hanya tampak di bagian depan saja. Jenis kain tenun so 'bbe sumelang secara umum dipakai oleh masyarakat luas. 
Jenis berikutnya dari kain tenun Pagatan yang dihasilkan oleh para penenun adalah kain tenun panji. Hiasan pada kain tenun panji ini tidak dibuat melalui teknik ikat atau songket, melainkan menganyam motif tertentu secara langsung. Dalam proses tersebut, benang pakan (passulu) dianyam pada benang dirian sau (masau) yang sudah tersusun pada tunggal hanian atau anagaliri. Hasil akhir dari penganyaman dua jenis benang tenun yang sudah diwarnai ini adalah sebuah ragam hias khusus sesuai dengan yang diinginkan oleh si penenun. Ragam hias yang terdapat pada tenun panji memilik bentuk yang beragam, seperti motif khas berupa kembang cengkeh. Adapun warna yang dominan adalah merah saga dan biru magenta (ungu) yang mengisi ruang kotak-kotak segi empat di atas warna dasar putih, kuning, hijau, abuabu, dan sebagainya. Kain tenun panji umumnya dipakai sebagai sarung (tapih kurung) untuk laki-laki, tetapi bisa juga dipakai untuk wanita. Karena fungsi dan cara pemakaiannya, kain tenun ini lebih dikenal dengan nama 'sarung Pagatan'.

Motif kotak-kotak yang terdapat pada kain tenun Pagatan sesungguhnya merupakan motif dasar saja. Pada perkembangannya motif kotak-kotak tersebut bisa digabungkan dengan berbagai motif lainnya. Motif dasar ini dapat diterapkan pada tenun so'bbe, baik so'bbe are maupun so'bbe sumelang. Motif kotak-kotak juga dapat dibuat dengan menganyam benang, seperti teknik yang diterapkan pada tenun panji. Selain itu, motif ini bisa juga dibuat dengan teknik mengikat benang, seperti yang diterapkan pada tenun bebbe.

\section{Fungsi dan Nilai}

Penggunaan kain tenun Pagatan senantiasa berkembang dari waktu ke waktu. Pada mulanya tenun Pagatan dibuat untuk kain sarung (tapih kurung) dan bahan pakaian yang berfungsi sebagai penutup dan pelindung tubuh pemakainya. Tenun dengan model dan motif tertentu semula hanya boleh dipakai oleh kaum laki-laki,serta pakaian untuk para raja atau kaum bangsawan, terutama Raja Bugis Pagatan. Pakaian raja atau bangsawan tersebut terdiri dari celana kerja yang disebut sulara pujama, baju, dan sarung. Tenun Pagatan untuk pakaian raja atau kalangan bangsawan ini terdiri dari beragam jenis, misalnya tenun Pagatan sarung bebbe pasulu, sarung bebbe sau, sarung songket, sarung so'bbe are, sarung so'bbe sumelang, dan sarung panji asolena. Kain-kain ini ditenun secara khusus oleh para wanita soraya dengan ornamen hias dan motif yang khas pula. Gambaran ini menunjukkan bahwa pemakaian kain tenun Pagatan dengan motif tertentu hanya khusus diperuntukan bagi kalangan bangsawan selaku kelompok elite. Fungsinya adalah sebagai penentu status sosial yang mencirikan identitas dan posisi pemakainya dalam suatu kelompok masyarakat, yakni orang Bugis Pagatan yang status sosialnya adalah sebagai bangsawan. 
Dalam perkembangannya, pemakai tenun Pagatan tidak lagi terbatas di kalangan bangsawan, melainkan dapat juga dipakai oleh masyarakat umum. Tenun Pagatan pun sudah banyak yang digunakan sebagai bahan dasar dalam pembuatan beraneka ragam jenis dan model pakaian, sesuai dengan selera pemakai atau pemesannya. Selain sarung, terdapat beberapa jenis dan pelengkap pakaian yang terbuat dari tenun Pagatan. Contohnya antara lain adalah dasi, stagen, selendang, baju biasa, rok, kain panjang, busana Muslim, dan pakaian tari. Kini, sarung dari tenun Pagatan pun tidak lagi hanya dipakai oleh kaum laki-laki, namun dipakai pula oleh kaum perempuan.

Kain tenun Pagatan dikenakan oleh kaum perempuan sebagai bagian dari pakaian tradisional perempuan Bugis yang disebut dengan bodo. Baju bodo dan pakaian tradisional masyarakat Bugis Pagatan yang terbuat dari kain tenun Pagatan dengan warna dan motif yang khas kerap dipakai untuk acaraacara khusus yang berkaitan dengan tradisi budaya mereka, seperti dalam acara mappandretasi' (pesta laut), mappabotting (perkawinan), massukkiri (pembacaan syair dan pantun), serta dalam pergelaran seni dan tari, misalnya tarian mapakaraja untuk menyambut tamu, tari japin, kesenian kecapi Bugis, hadrah, dan lain-lain.

Fungsi yang lain dari kain tenun Pagatan adalah untuk menunjukkan posisi atau kedudukan dari pemakainya. Selain, menunjukkan bahwa pemakainya seorang dari kalangan bangsawan, tenun Pagatan juga mencirikan bahwa pemakainya adalah seorang pedagang besar atau seorang tetuo adat, misalnya sandro. Sandro adalah seorang yang dianggap memiliki kemampuan khusus dalam masyarakat Bugis Pagatan, misalnya pandai memberi pengobatan, pandai memberi petuah atau petunjuk tentang daerah-daerah tangkapan ikan, pemimpin dalam upacara mappandretasi' dan upacara-upacara yang lainnya.

Fungsi kain tenun Pagatan yang lain adalah sebagai barang hantaran yang menjadi syarat dalam tradisi perkawinan masyarakat Bugis Pagatan. Tenun Pagatan menyertai barangbarang lain yang dihantarkan oleh pihak laki-laki kepada pihak wanita sebelum acara perkawinan dilangsungkan. Kain tenun Pagatan yang menjadi barang hantaran untuk acara peminangan perkawinan (mappaboting) ini harus terbuat dari jenis kain yang berkualitas, misalnya berbahan sutra, dengan tenunan yang terbaik, dan dengan motif yang khas pula.

Berdasarkan penjelasan di atas, fungsi kain tenun Pagatan sejak dulu hingga sekarang tidak hanya sebatas untuk menutup dan melindungi tubuh pemakainya, tetapi dipakai pula sebagai pakaian dalam upacara adat. Selain itu tenun Pagatan dapat diberikan kepada orang lain sebagai bentuk penghargaan dan hantaran dalam perkawinan (maskawin). Di dalam kegiatan di bidang ekonomi, tenun Pagatan dapat diperjualbelikan atau komoditas yang diperdagangkan. Di dalam relasi sosial, 
tenun Pagatan sebagai perlambang prestise seseorang yang menduduki strata sosial tertentu dalam kehidupan masyarakat. Di zaman dulu kain tenun Pagatan juga dianggap menjadi penanda atau identitas pemakainya sebagai orang Bugis Pagatan (to ugie). Dalam hal tertentu, kain tenun Pagatan juga berfungsi sebagai alat penebus atau pembayar denda atas pelanggaran adat yang dilakukan seseorang. Menurut kepercayaan sebagian orang Bugis Pagatan, kain tenun Pagatan adalah pembawa keberuntungan, kesuksesan, atau keselamatan, terutama ketika mereka sedang bepergian, melaut, atau bekerja.

\section{Peluang Ekonomi}

Secara ekonomi, kegiatan menenun merupakan salah satu usaha yang bisa menambah penghasilan keluarga, karena tenun Pagatan yang dihasilkan dari kegiatan tersebut adalah komoditas perdagangan yang memiliki nilai jual cukup tinggi. Nilai jual tenun Pagatan akan semakin tinggi jika dibuat dari bahan-bahan yang berkualitas dan dengan motif yang khusus. Kain Pagatan dengan kualitas yang paling baik (bahannya dari sutra), harga perlembarnya bisa mencapai sejuta rupiah atau lebih. Tenun songket asli dengan motif sulur yang menggunakan campuran benang emas, harganya pun bisa mencapai jutaan rupiah. Tenun Pagatan bermotif tenun ikat lusi dan ikat pakan, rata-rata dijual di kisaran harga Rp 500.000. Namun bahan pakaian siap pakai yang terbuat dari tenun Pagatan dijual dengan harga yang lebih tinggi. Kain Pagatan dengan kualitas biasa dan dengan motif yang umum dijual dengan harga lebih murah, antara Rp 150.000 hingga $\mathrm{Rp} 250.000$ per lembar.

Pada puncak perkembangannya, banyak bermunculan sentra-sentra tenun yang memproduksi tenun Pagatan. Sentra-sentra ini tersebar di berbagai desa di wilayah Kecamatan Kusan Hilir Pagatan, seperti seperti Desa Manurung, Mudalang, Mattone Kampung Baru, Barugelang, Batarang, Saring Sungai Binjai, Sepunggur, dan Kelurahan Pagatan.

Peluang ekonomi dari keberadaan tenun Pagatan juga bisa dilihat dari segi pemanfaatan atau fungsinya. Meskipun pada mulanya tenun Pagatan hanya dipakai di kalangan tertentu, namun dalam perkembangannya mengalami perluasan dari sisi pemakai, hingga kini dapat dipakai oleh masyarakat umum. Perubahan ini mendatangkan keuntungan bagi para perajin tenun Pagatan, karena permintaan akan tenun menjadi semakin tinggi. Dengan demikian kelangsungan mata pencaharian para penenun tetap terjaga. Pengetahuan mereka tentang tenun pun menjadi semakin meningkat dengan berbagai inovasi yang dilakukan.

Peluang ekonomi dari kain tenun Pagatan juga bisa dilihat dari kekhasan motif dan kecocokannya untuk dipakai oleh masyarakat Indonesia yang umumnya berdiam di daerah tropis. Menurut Salmah, yang menjadi ciri khas tenun Pagatan adalah kainnya yang halus, terasa dingin ketika digunakan, 
dengan warna-warni cerah, seperti merah, biru, kuning, dan hijau, serta motif khas etnik Pagatan. Kain tenun Pagatan sangat cocok untuk dijadikan pakaian di daerah panas atau tropis (Wawancara Salmah, Pagatan, 15 April 2016).

Seiring dengan perjalanan waktu, perkembangan kain tenun Pagatan mengalami masa naik dan turun. Di tahun 1990-an, kain tenun Pagatan sempat mengalami kemajuan produksi dan perkembangan yang signifikan. Peristiwa ini ditandai dengan semakin bertambah banyaknya jumlah perajin kain atau penenun serta bermunculannya rumah produksi atau sentra-sentra tenun Pagatan yang tersebar di Kecamatan Kusan Hilir Pagatan. Namun, di tahun 2000-an, keberadaan kain tenun Pagatan sempat meredup dan produksinya mengalami penurunan. Kondisi ini terjadi seiring dengan semakin banyaknya jenis kain yang beredar dipasaran dengan harga yang lebih murah, mahalnya ongkos produksi kain tenun Pagatan, kurangnya pembinaan di sektor produksi, kurangnya inovasi dan kreasi perajin, serta berbagai faktor lainnya, membuat (Wawancara Ishak, Pagatan, 14 April). Di masa itu jumlah perajin tenun Pagatan semakin berkurang. Demikian pula dengan sentra industri rumahan tenun Pagatan yang juga mengalami penurunan. Sentra usaha tenun Pagatan yang semula tersebar di banyak desa di Kecamatan Kusan Hilir Pagatan, pada akhirnya hanya ada di dua desa, yakni di Desa Manurung (Subarang) dan
Madulang. Sentra tenun Pagatan yang bertahan itu misalnya "Berkat Setia" yang berlokasi di Jalan H.M. Amin RT 3 Desa Mudalang, serta Koperasi Tenun Pertiwi, Butik Sederhana Salmah, dan Mega Tenun yang berlokasi di Jalan Raya Desa Manurung (Subarang) Pagatan Kecamatan Kusan Hilir Kabupaten Tanah Bumbu.

Faktor lain yang membuat produksi tenun Pagatan mengalami kemunduran adalah semakin berkurangnya generasi penerus (terutama remaja putri) yang mau meneruskan dan menggeluti usaha tenun ini. Padahal, menurut Salmah keterampilan menenun harus sudah dipelajari oleh seorang anak gadis sejak masih kecil. Menurutnya, dia telah belajar menenun sejak masih duduk di bangku sekolah dasar. Penguasaan pengetahuan dalam menenun itu semakin meningkat, hingga dia mampu membuat dan merancang motif-motif tenun. Keterampilan menenun didapatkan Salmah dari orangtua dan neneknya, dan akan terus diwariskan secara turun temurun kepada keturunan berikutnya (Wawancara Salmah, Pagatan, 15 April 2016).

Namun saat ini sudah terjadi perubahan. Tak banyak lagi remaja putri yang tertarik dengan keterampilan menenun kain Pagatan. Meskipun sesungguhnya pada masyarakat Bugis Pagatan terdapat pandangan bahwa para wanita harus pandai memintal benang, mengikat dan mewarnai benang dirian, hingga kemudian menenunnya (Wawancara Suriani, Pagatan, 17 April 2016). Boleh jadi penurunan minat ini 
disebabkan karena pengetahuan dan keterampilan menenun relatif sulit untuk dipelajari. Seperti diketahui, pekerjaan menenun adalah aktivitas yang memerlukan pengetahuan, keterampilan, ketelitian, serta ketelatenan yang tinggi. Bahkan pada masyarakat tertentu, para penenun mendendangkan syair-syair pujaan di saat sedang menenun, sebagai refleksi dari harapan hidup antara hasil pekerjaan dengan si pemakainya nanti. Ada pula penenun yang melakukan tradisi tertentu sebelum mulai menenun, misalnya berpuasa, berpantang, melaksanakan tabu atau pamali tertentu, ataupun menyediakan semacam sesaji [bahasa Banjar: piduduk], dengan tujuan supaya pekerjaan mereka dapat berjalan dengan lancar. Tradisi seperti ini dilakukan oleh para penenun yang menyiapkan kain tenun untuk raja atau kaum bangsawan, karena biasanya kain-kain tersebut terbuat dari bahan dan dengan motif yang khusus (Sulaksono, 2015:13).

Berkurangnya minat remaja putri dalam menggeluti tradisi menenun ini bisa disebabkan oleh beberapa faktor, di antaranya kesibukan mereka dalam mengikuti berbagai aktivitas, terutama dengan padatnya aktivitas di sekolah, sehingga tidak memiliki waktu luang untuk mempelajari dan melakukan pekerjaan menenun. Apalagi hingga kini pengetahuan dan keterampilan menenun ini belum dijadikan sebagai muatan lokal dan diajarkan di sekolahsekolah. Padahal, di zaman dahulu kaum perempuan Pagatan yang berusia sekitar 15-17 tahun sudah terampil dalam menenun kain. Kepandaian menenun tersebut terus dipertahankan hingga mereka semakin dewasa dan berkeluarga.

Bahkan, dalam tradisi Bugis Pagatan terdapat aturan adat yang mengharuskan seorang gadis yang dianggap telah memasuki usia yang cukup untuk menikah, hanya boleh menenun kain dalam ruangan khusus yang tidak boleh dimasuki oleh sembarang orang. Dalam melakukan pekerjaannya tersebut, seorang gadis dapat menggunakan tamrajeng, yaitu alat tenun yang dapat menimbulkan bunyi pada saat merapatkan benang pasulu, sehingga orang yang mendengar bunyi tersebut tahu bahwa di dalam ruangan itu ada gadis yang sedang menenun kain (Sulaksono, 2015:74). Di samping itu, seorang gadis Bugis Pagatan yang pandai menenun dipandang memiliki daya tarik yang lebih tinggi, serta memiliki modal dasar untuk memasuki kehidupan rumah tangga nantinya (Wawancara Mariani, Pagatan, 14 April 2016). Penguasaan keterampilan menenun menjadi salah satu kriteria penting yang harus dimiliki oleh seorang gadis sehingga bisa dianggap sebagai calon istri ideal, selain sejumlah kriteria lainnya yang berkaitan dengan sikap dan perilaku, tata krama dan sopan santun, kemampuan mengerjakan pekerjaan rumah tangga, cara berpakaian, dan latar belakang kehidupan keluarganya. 


\section{Upaya Pengembangan}

Menurut Mariani, dahulu kaum wanita Bugis Pagatan banyak yang menekuni tradisi menenun. Namun di masa sekarang tradisi menenun ini menghadapi tantangan yang berat dengan semakin berkurangnya peminat atau generasi penerus yang mau menggeluti dan meneruskan usaha menenun (Wawancara Mariani, Pagatan, 14 April 2015). Padahal, di masa jayanya, desa-desa yang menjadi sentra penghasil kain tenun Pagatan diramaikan oleh suara mesin tenun yang terus berputar, yang menunjukkan kegairahan dan perkembangan yang cerah. Para penenun tradisional yang terdapat di desa-desa di Kecamatan Kusan Hilir Pagatan memiliki keahlian tersendiri. Mereka mampu berkolaborasi dengan baik antara satu penenun dengan penenun yang lain, meskipun berasal dari desa yang berbeda. Misalnya, bahan dasar kain berupa benang dipintal di Desa Manurung, kemudian proses pengikatannya dilakukan di Desa Mudalang, tahap pewarnaan dilakukan di Desa Saring Sungai Binjai, kemudian ditenun hingga menjadi kain khas Pagatan dengan motif yang menarik di Desa Barugelang.

Namun, sejak tahun 2000-an hingga sekarang, usaha menenun dianggap tidak lagi menjadi usaha yang menjanjikan. Kain tenun Pagatan telah mengalami penurunan, tidak hanya dari segi jumlah produksi, angka pemesanan dan jangkauan pemasaran, tetapi juga dari segi jumlah penenun dan sentra- sentra usaha yang membuat kain tenun Pagatan juga mengalami penurunan secara drastis. Menurut Ishak, jumlah penenun yang hingga sekarang masih menggeluti usaha tenun kain Pagatan jumlahnya tinggal 15 sampai 20 perajin (Wawancara Ishak, Pagatan, 14 April 2016).

Kondisi seperti ini tentu saja tidak ideal, sehingga diperlukan upaya dan penanganan yang serius untuk membangkitkan kembali usaha kerajinan dan potensi desa penghasil tenun. Kain tenun Pagatan sendiri memiliki potensi dan peluang untuk berkembang dan terus lestari di masamasa yang akan datang melalui usahausaha dan komitmen semua pihak yang berkepentingan.

Upaya yang bisa dilakukan oleh pemerintah daerah tentu saja berkaitan dengan pembinaan terhadap para perajin, misalnya dengan memberikan bantuan pelatihan, permodalan, dan sekaligus pemasaran. Di samping itu, penting juga dilakukan serangkaian upaya yang bersifat sistematis, seperti: 1) menjadikan tenun Pagatan sebagai salah satu pakaian resmi sekolah dan pakaian resmi kerja diberbagai lembaga pendidikan dan instansi pemerintahan; 2) menjadikan tenun Pagatan sebagai pakaian budaya sebagai ciri khas masyarakat dari Pagatan ketika pelaksanaan kegiatan-kegiatan tertentu, misalnya kegiatan budaya, kegiatan olahraga, kegiatan keagamaan, hari jadi daerah, dan lain-lain; 3) membangun pusat-pusat kerajian tenun Pagatan yang menjadi sentra untuk produksi, 
Handep, Vol. 1, No. 2, Juni 2018 : 35-58

pelatihan, dan sekaligus penelitian dalam rangka pengembangan dan inovasi kain tenun Pagatan agar lebih menarik dan sesuai dengan tren atau perkembangan mode saat ini; 4) menjadikan kerajinan tenun Pagatan sebagai salah satu mata pelajaran muatan lokal yang diajarkan secara khusus di sekolah-sekolah untuk menumbuhkan minat generasi muda terhadap kerajinan tenun ini atau menjadikan keterampilan menenun sebagai salah satu Program Keahlian (PK) di Sekolah Menengah Kejuruan (SMK) yang ada di Pagatan, sehingga menenun bisa dipelajari secara lebih sistematis.

Berdasarkan kenyataan di atas, maka usaha-usaha untuk mengangkat kembali kain tenun Pagatan agar terus mampu berkembang dan tetap bertahan telah banyak dilakukan oleh Pemerintah Kabupaten Tanah Bumbu, seperti menetapkan dan menjadikan kain tenun Pagatan sebagai baju resmi di lembaga pendidikan atau kantor pemerintahan untuk dipakai pada hari-hari tertentu; menjadi baju resmi kedaerahan yang dipakai dalam acara atau tradisi budaya ataupun kegiatan resmi pemerintahan; menjadi baju jemaah haji asal Kabupaten Tanah Bumbu; dijadikan sebagai oleh-oleh bagi setiap orang yang berkunjung ke Tanah Bumbu.

Di samping itu, Pemerintah Kabupaten Tanah Bumbu juga harus melakukan pembinaan secara berkesinambungan terhadap para perajin kain tenun Pagatan, baik dalam hal produksi, pengemasan, pemasaran, peningkatan kualitas, maupun permodalan.

\section{PENUTUP}

Kain tenun Pagatan dihasilkan melalui proses yang panjang, dimulai dari penyiapan bahan-bahan berkualitas terutama benang, penyiapan peralatan tenun yang memadai terutama gedok, serta teknik cerdas menenun yang telah diwarisi.

Kain tenun Pagatan memiliki keindahan warna dan motif yang bersifat khas yang berfungsi tidak hanya sebagai bahan pakaian yang biasa dipakai dalam kehidupan sehari-hari, tetapi juga sebagai simbol budaya dan sosial pemakainya. Oleh karena itu, tenun Pagatan mendominasi dalam upacara adat atau tradisi, tenun Pagatan juga menyiratkan identitas pemakainya sebagai orang Bugis Pagatan (to ugie), dan menyimbolkan status sosial pemakainnya.

Pada saat sekarang ini dengan semakin meluasnya fungsi dan penggunaan kain tenun Pagatan serta kekhasan coraknya atau keindahan motif tenunannya dan kualitas bahan yang digunakan merupakan bagian penting sekaligus peluang ekonomi kain tenun Pagatan untuk menjadi komoditas yang menarik banyak orang untuk membelinya.

Pengembangan dan inovasi kain tenun Pagatan harus senantiasa dilakukan, tidak hanya oleh para penenun dengan memadukan, menginovasi, ataupun merancang ulang motif-motif yang menarik tetapi juga 
pembinaan oleh Pemerintah Daerah, sehingga keterampilan menenun dan kekhasan kain Pagatan tidak hilang. Sebaliknya, menjadi potensi ekonomi dan kebanggaan daerah yang bisa dipopulerkan dalam berbagai kegiatan, sehingga menjadi nilai tambah kesejahteraan bagi para penenun.

\section{DAFTAR SUMBER}

Basrowi dan Suwandi. 2008. Memahami Penelitian Kualitatif. Jakarta: PT. Rineka Cipta.

Bogdan, Robert C. dan Sari Knopp Biklen. 1982. Qualitative Research for Education: An Introduction to Theory and Methods. Boston: Allyn and Bacon.

Creswell, John W. 1994. Research Design Quantitative And Qualitative Approach. London: Sage Publication.

Hidayah, Sri. 2014. Eksotika Tenun Pagatan. Banjarmasin: PT. Grafika Wangi Kalimantan Selatan.

http://information of-world. blogspot.co.id/2014/10/macam$\mathrm{m}$ a c a m - k a i n - m a k n a simbolik.html, diakses pada Januari 2018

Sjarifuddin, et al. 1991. Tenun Pagatan. Banjarbaru: Museum Lambung Mangkurat.
Sulaksono, Dwi Putro. 2015. Wastra Tenun Kalimantan Selatan. Banjarmasin: Pustaka Banua.

Surachmad, Winarno. 1982. Dasar dan Teknik Research. Bandung: Tarsito.

Pusat Bahasa Departemen Pendidikan Nasional. Kamus Bahasa Indonesia, 2008.

Wawancara. Andi Satria Jaya. Pagatan, 12 April 2016

Wawancara. Ishak. Pagatan, 14 April 2016

Wawancara. Mariani. Pagatan, 14 April 2016.

Wawancara. Salmah. Pagatan, 15 April 2016.

Wawancara. Suriani. Pagatan, 17 April 2016.

Yin, Robert K. 1996. Studi Kasus: Desain dan Metode. Jakarta: PT. Raja Grafindo Persada. 
